\title{
Tissue plasminogen activator inhibitor in patients with systemic lupus erythematosus and thrombosis
}

\author{
Francesco Violi, Domenico Ferro, Guido Valesini, Claudio Quintarelli, Mirella Saliola, \\ Maria A Grandilli, Francesco Balsano
}

\begin{abstract}
Objective-To examine the relations among tissue plasminogen activator antigen, plasminogen activator inhibitor, the lupus anticoagulant, and anticardiolipin antibodies in patients with systemic lupus erythematosus.
\end{abstract}

Design-Prospective study of blood samples $(a)$ from selected patients with systemic lupus erythematosus whose disease was and was not complicated by a history of thrombosis or recurrent abortions, or both, and $(b)$ from a series of healthy controls with a similar age and sex distribution.

Setting-University based medical clinic.

Subjects - 23 Patients with definite systemic lupus erythematosus (American Rheumatism Association criteria), of whom 11 (eight women) aged 26-51 had a history of thrombosis or recurrent abortions, or both, and 12 (10 women) aged 23-53 had no such history. 15 Healthy subjects (10 women) aged $25-58$ served as controls.

Main outcome measures-Tissue plasminogen activator concentrations, plasminogen activator inhibitor activities, detection of the lupus anticoagulant, and values of anticardiolipin antibodies in the two groups of patients and in the patients with a history of thrombosis or abortions compared with controls. Other measurements included concentrations of proteins that are known to change during the acute phase of systemic lupus erythematosusnamely, fibrinogen, $\mathrm{C} 3$ and $\mathrm{C} 4$, and $\mathrm{C}$ reactive protein.

Results-Patients with a history of thrombosis or abortions, or both, had significantly higher values of tissue plasminogen activator and plasminogen activator inhibitor than patients with no such history. A significant correlation between tissue plasminogen activator and plasminogen activator inhibitor $(r=$ $0 \cdot 80$ ) was found only in the patients with a history of complications of their disease. The lupus anticoagulant was detected in six of the 11 patients with a history of thrombosis or abortions when tested by measuring the activated partial thromboplastin time but was found in all 11 patients when tested by measuring the diluted activated partial thromboplastin time. Nine of these 11 patients had raised values of anticardiolipin antibodies. The findings showed no relation to the activity of the disease.

Conclusions-A significant correlation between tissue plasminogen activator concentrations and plasminogen activator inhibitor activities was found only in patients whose systemic lupus erythematosus was complicated by a history of thrombosis or recurrent abortions. The findings show that these patients have raised plasminogen activator inhibitor activities, and the frequent association between these raised activities and the presence of the lupus anticoagulant suggests that the two may be linked.

\section{Introduction}

Patients with systemic lupus erythematosus may have thrombotic episodes or a history of recurrent abortions. ${ }^{12}$ These events are often associated with the presence of the lupus anticoagulant, an IgG or IgM immunoglobulin that interacts with phospholipid in the coagulation system. ${ }^{34}$

There is a high incidence of thrombosis in patients with systemic lupus erythematosus and the lupus anticoagulant. Roughly a third to half of patients with the lupus anticoagulant have a clinical history that includes thrombotic episodes or abortions. ${ }^{5}$ The pathophysiological mechanism of this association has not been clarified. Some workers have hypothesised that the thrombosis is linked to a reduced vascular production of prostacyclin, ${ }^{6}$ a platelet aggregation inhibitor and vasodilator substance, but other, more recent studies do not support this. ${ }^{78}$ In some cases thrombotic events occur in patients with the lupus anticoagulant and thrombocytopenia, and it has been suggested that the thrombotic condition may be linked to platelet activation in vivo. ${ }^{9}$ This hypothesis has not been confirmed. ${ }^{5}$ Lastly, other studies have found decreased fibrinolytic activity in most patients with systemic lupus erythematosus, but neither the relation between this finding and thrombosis nor that between the lupus anticoagulant and thrombosis was clear. ${ }^{1011}$

As decreased fibrinolytic activity is an important risk factor in thromboembolism we studied this activity in patients with systemic lupus erythematosus. We measured blood concentrations of tissue plasminogen activator and activities of its inhibitor, ${ }^{12}$ correlating them with a history of thrombotic episodes or recurrent abortions. This paper presents our results.

\section{Subjects and methods}

We studied 23 patients diagnosed as having systemic lupus erythematosus (American Rheumatism Association criteria). ${ }^{13}$ Eleven of the patients (eight women, three men; age range 26-51) had a history of thrombosis or recurrent abortions, or both, over the previous one to eight years (group 1). The diagnosis of thrombosis and abortions was based on clinical and laboratory findings. These patients were compared with 12 others ( 10 women, two men; age range $23-53$ ) who had no clinical history of thrombotic events or abortions (group 2). In group 1 the clinical history of systemic lupus erythematosus had begun an average of seven years before (range 1-16 years), and in group 2 it had begun an average of nine years before (range 1-17 years). The patients were considered to be in a severely active, moderately active, or inactive phase of the disease based on the occurrence of three, one or two, or none of the following in the three months preceding the study ${ }^{14}$ : arthralgia; pleuritis, pericarditis; vasculitis; myalgia; renal or nervous system involvement.
Medicine I, Policlinico Italy.

Br.Med f 1990;300: 1099-102




Among the measurements in the two groups of patients we included the concentrations of some proteins that are known to change during the acute phase of systemic lupus erythematosus-namely, fibrinogen ${ }^{15}$ and $\mathrm{C} 3$ and $\mathrm{C} 4$ (measured by radial immunodiffusion $^{16}$ ) and $\mathrm{C}$ reactive protein (measured by an agglutination test ${ }^{17}$ ).

All except three patients (one in group 1, two in group 2) were being treated with prednisone $(5-25 \mathrm{mg} /$ day) or methylprednisolone $(4-24 \mathrm{mg} / \mathrm{day})$. None of the patients had received anticoagulant, antiaggregant, or fibrinolytic treatment in the month before the study.

Fifteen healthy volunteers served as controls. Ten were women and five men, and their ages ranged from 25 to 58 .

\section{BLOOD COAGULATION STUDY}

Blood samples taken between 9 and 10 am from each patient after fasting for 12 hours and resting for at least 10 minutes were mixed with $0 \cdot 13 \mathrm{M}$ sodium citrate (Becton Dickinson Vacutainer; ratio 9:1). The samples were centrifuged for 10 minutes at $2000 \mathrm{~g}$ at $4^{\circ} \mathrm{C}$. Part of the supernatant was prepared immediately for the measurement of fibrinogen concentration and the detection of the lupus anticoagulant and part stored at $-20^{\circ} \mathrm{C}$ for measurements of tissue plasminogen activator antigen concentration and plasminogen activator inhibitor activity.

The coagulation study for the lupus anticoagulant comprised measurement of the activated partial thromboplastin time, performed with a standard phospholipid mixture (Thrombofax reagent, Ortho Diagnostics Johnson and Johnson, New Jersey; reference value 23-29 S), and measurement of the diluted activated partial thromboplastin time, performed with serial phospholipid dilutions. ${ }^{18}$ The diluted activated partial thromboplastin time was measured as follows. The patient's plasma was mixed in a 1:1 ratio with normal plasma to allow for the replacement of any deficiency. A $0 \cdot 1 \mathrm{ml}$ sample of this mixture was incubated for two minutes at $37^{\circ} \mathrm{C}$ and then mixed with $0 \cdot 1 \mathrm{ml}$ kaolin suspension (Boehringer Mannheim, West Germany) and $0.1 \mathrm{ml}$ Thrombofax reagent diluted 15 to 180 with veronal buffer at $\mathrm{pH} 7 \cdot 4$. Clotting time was recorded after adding $0.025 \mathrm{M}$ calcium chloride. In the 15 healthy subjects the mean difference between 15 and 180 dilutions of Thrombofax reagent was $9(\mathrm{SD} 2 \cdot 8) \mathrm{s}$. The diluted activated partial thromboplastin time was considered abnormal if the difference between the 15 and 180 dilutions of Thrombofax reagent was $>15 \mathrm{~s}$ (mean plus $2 \mathrm{SD}$ of the control value).

The tissue plasminogen activator antigen concentration was measured by an enzyme linked immunosorbent assay (ELISA; Imubind-5-tPA, American Diagnostics, New York). ${ }^{19}$ The concentration was expressed as $\mu \mathrm{g} / \mathrm{l}$. Activity of the rapid tissue plasminogen activator inhibitor was assessed by adding a fixed amount of tissue plasminogen activator to diluted plasma and determining the residual activity by measuring the amidolytic activity of plasmin on the chromogenic substrate S-2251 (Kabi Vitrum,

TABLE I-Severity of illness and concentrations of acute reactant phase proteins in 23 patients with systemic lupus erythematosus whose disease was and was not complicated by history of thrombosis or abortions, or both

\begin{tabular}{|c|c|c|}
\hline & $\begin{array}{l}\text { Patients with history of } \\
\text { thrombosis or abortions } \\
\quad \text { (group } 1 ; n=11)\end{array}$ & $\begin{array}{l}\text { Patients with no history of } \\
\text { thrombosis or abortions } \\
\quad \text { (group } 2 ; \mathrm{n}=12 \text { ) }\end{array}$ \\
\hline \multicolumn{3}{|l|}{ Activity of systemic lupus erythematosus: } \\
\hline No with severely active disease & 5 & 3 \\
\hline No with moderately active disease & 3 & 5 \\
\hline No with inactive disease & 3 & 4 \\
\hline \multicolumn{3}{|l|}{ Acute reactant phase proteins: } \\
\hline $\mathrm{C} 3(\mathrm{~g} / \mathrm{l})($ reference value $1 \cdot 2-2 \cdot 0)$ & $1.51(\mathrm{SD} 0.58)$ & $1 \cdot 37(\mathrm{SD} 0 \cdot 40)$ \\
\hline $\mathrm{C} 4(\mathrm{~g} / \mathrm{l})($ reference value $0 \cdot 3-0 \cdot 5)$ & $0.39(\mathrm{SD} 0.27)$ & $0.40(\operatorname{SD~} 0 \cdot 17)$ \\
\hline Fibrinogen $(\mathrm{g} / \mathrm{l})($ reference value $1 \cdot 8-4 \cdot 0)$ & $2.65(\mathrm{SD} 0.43)$ & $2 \cdot 89(\mathrm{SD} 0.64)$ \\
\hline
\end{tabular}

Stockholm). In this system one unit of the inhibitor is the amount that inhibits $1 \mathrm{U}$ of tissue plasminogen activator..$^{20}$ Tissue plasminogen activator concentrations and plasminogen activator inhibitor activities were also measured in the 15 healthy subjects. The mean values were $4 \cdot 2(\mathrm{SD} 1 \cdot 3) \mu \mathrm{g} / \mathrm{l}$ and $7 \cdot 9(2 \cdot 8) \mathrm{U} / \mathrm{ml}$ respectively.

Anticardiolipin antibodies were assayed as described. ${ }^{21}$ Briefly, 95 well, flat bottomed, rigid polystyrene electroimmunoassay microtitration plates (Dynatech) are coated $(30 \mu \mathrm{l} /$ well) with bovine heart cardiolipin (Sigma Chemical Company, St Louis, Missouri) diluted in ethanol. The ethanol is evaporated by leaving the plates uncovered overnight at $4^{\circ} \mathrm{C}$. After the plates have been dried they are washed twice with phosphate buffered saline (pH 7.3) $100 \mu \mathrm{l} /$ well. The plates are blocked $(75 \mu \mathrm{l} /$ well $)$ with $10 \%$ fetal calf serum in phosphate buffered saline for one hour. Aliquots $(50 \mu \mathrm{l})$ of normal human serum, positive control samples, and test samples at 1/50 dilution in phosphate buffered saline-fetal calf serum $(10 \%)$ are then added to triplicate wells and incubated for three hours at room temperature. The plates are then washed three times with phosphate buffered saline, and alkaline phosphatase labelled affinity isolated goat antihuman IgG or IgM, or both, diluted $1 / 1000$ in phosphate buffered saline-fetal calf serum is added $(50 \mu \mathrm{l} /$ well $)$. Plates are incubated for 30 minutes at room temperature. The conjugate is discarded and the plates washed three times with phosphate buffered saline. Substrate $(50 \mu \mathrm{l} /$ well) is then added. The substrate is prepared by adding one tablet of $p$-nitrophenyl phosphate (Sigma) per $5-6 \mathrm{ml}$ diethanolamine buffer. After addition of substrate the reaction is allowed to take place in the dark at $37^{\circ} \mathrm{C}$, and when the highest positive control value reaches an absorbance reading of about 0.8 to 0.9 for both the IgG and IgM samples the reaction is stopped by adding $3 N$ sodium hydroxide $75 \mu \mathrm{l} /$ well. Absorbance is read at $405 \mathrm{~nm}$ using a multiscanner. The results are expressed as the number of standard deviations above the mean in normal human serum (reference value $<3 \mathrm{SD}$ ).

\section{STATISTICAL ANALYSIS}

Kruskal-Wallis one way analysis of variance, the Mann-Whitney test, and linear correlation were performed with the STAT view II program. Significance was accepted at $\mathrm{p}<0 \cdot 05$.

\section{Results}

The severity of illness and concentrations of the acute reactant phase proteins $(\mathrm{C} 3, \mathrm{C} 4$, and fibrinogen) were similar in the two groups of patients (table I). $C$ reactive protein was detected in five of the 11 patients with a history of thrombosis or recurrent abortions, or both (group 1), and in eight of the 12 patients with no such history (group 2). In group 1 six patients had suffered thrombophlebitis, six had had abortions, one had had a stroke, and one had had pulmonary thrombosis; four patients had a history of abortions only (table II).

Tissue plasminogen activator concentrations and plasminogen activator inhibitor activity differed significantly (Kruskal-Wallis, $p=0.0004$ and $p=0.0002$ ) between the two groups of patients and the controls. Intergroup analysis by the Mann-Whitney test showed that values of tissue plasminogen activator and plasminogen activator inhibitor were significantly higher in the patients in group 1 than in those in group 2 (tissue plasminogen activator, $\mathrm{p}<0.002$; plasminogen activator inhibitor, $\mathrm{p}=0.0007)$ and the controls (tissue plasminogen activator, $\mathrm{p}<0.002$; plasminogen activator inhibitor, $p=0 \cdot 0002$ ). No significant differences in tissue plasminogen activator concentrations or 


\begin{tabular}{|c|c|c|c|c|c|c|}
\hline Case No & Clinical events & $\begin{array}{l}\text { Activated partial } \\
\text { thromboplastin time }(\mathrm{s})\end{array}$ & $\begin{array}{l}\text { Diluted activated partial } \\
\text { thromboplastin time }(\mathrm{s})\end{array}$ & $\begin{array}{l}\text { Tissue plasminogen activator } \\
(\mu \mathrm{g} / \mathrm{l})\end{array}$ & $\begin{array}{l}\text { Plasminogen activator } \\
\text { inhibitor }(\mathrm{U} / \mathrm{ml})\end{array}$ & $\begin{array}{c}\text { Anticardiolipin antibodies } \\
\text { (SDs above mean in } \\
\text { normal human serum) }\end{array}$ \\
\hline \multicolumn{7}{|c|}{ Patients with history of thrombosis or abortions, or both (group l) } \\
\hline 1 & $\begin{array}{l}1 \text { Episode of thrombophlebitis, } \\
1 \text { miscarriage }\end{array}$ & $35 \cdot 8$ & $33 \cdot 0$ & $11 \cdot 5$ & $40 \cdot 6$ & $\operatorname{IgG} 12 \cdot 5, \operatorname{IgA} 11 \cdot 2$ \\
\hline \multirow[t]{2}{*}{2} & Recurrent thrombophlebitis, & & & & & \\
\hline & 1 miscarriage & $47 \cdot 9$ & $23 \cdot 0$ & $15 \cdot 0$ & $39 \cdot 0$ & - \\
\hline 3 & 1 Miscarriage & $22 \cdot 5$ & $27 \cdot 0$ & $5 \cdot 5$ & $21 \cdot 0$ & - \\
\hline 4 & Recurrent thrombophlebitis & $37 \cdot 5$ & $32 \cdot 5$ & $5 \cdot 9$ & $25 \cdot 0$ & $\operatorname{Ig} M 18 \cdot 5$ \\
\hline 5 & Recurrent thrombophlebitis & $23 \cdot 0$ & $21 \cdot 0$ & $6 \cdot 3$ & $24 \cdot 5$ & IgG $8 \cdot 2$ \\
\hline 6 & 3 Miscarriages & $24 \cdot 5$ & $27 \cdot 0$ & $6 \cdot 0$ & $14 \cdot 0$ & $\operatorname{IgG} 25 \cdot 0, \operatorname{IgM} 4 \cdot 0$ \\
\hline \multirow[t]{2}{*}{7} & Recurrent thrombophlebitis, & & & & & \\
\hline & 1 stroke & $34 \cdot 3$ & $42 \cdot 0$ & $6 \cdot 6$ & $30 \cdot 0$ & $\operatorname{IgG} 28 \cdot 4$ \\
\hline 8 & 5 Miscarriages & $24 \cdot 0$ & $17 \cdot 0$ & $8 \cdot 0$ & $15 \cdot 3$ & $\operatorname{IgG} 3 \cdot 7, \operatorname{IgA} 6 \cdot 2$ \\
\hline \multirow{2}{*}{9} & 1 Episode of pulmonary & & & & & \\
\hline & arterial thrombosis & $40 \cdot 4$ & $26 \cdot 0$ & $9 \cdot 1$ & $20 \cdot 8$ & $\operatorname{IgG} 5 \cdot 4$ \\
\hline 10 & Recurrent thrombophlebitis & $57 \cdot 4$ & $58 \cdot 0$ & $15 \cdot 3$ & $35 \cdot 6$ & $\operatorname{IgG} 50 \cdot 0$ \\
\hline 11 & 2 Miscarriages & $23 \cdot 0$ & $20 \cdot 0$ & $3 \cdot 0$ & $6 \cdot 8$ & $\operatorname{lgG} 8 \cdot 2$ \\
\hline \multicolumn{7}{|c|}{ Patients with no history of thrombosis or abortions (group 2) } \\
\hline 12 & - & $30 \cdot 4$ & $18 \cdot 5$ & $6 \cdot 2$ & $13 \cdot 5$ & $\operatorname{lgG} 3 \cdot 7$ \\
\hline 13 & - & $23 \cdot 0$ & $13 \cdot 0$ & $2 \cdot 6$ & $7 \cdot 5$ & - \\
\hline 14 & - & $25 \cdot 0$ & $10 \cdot 2$ & $11 \cdot 0$ & $11 \cdot 5$ & - \\
\hline 15 & - & $24 \cdot 0$ & $10 \cdot 0$ & $2 \cdot 8$ & $2 \cdot 0$ & - \\
\hline 16 & - & $23 \cdot 0$ & $13 \cdot 0$ & $2 \cdot 9$ & $10 \cdot 8$ & $\operatorname{IgA} 10 \cdot 6$ \\
\hline 17 & - & $23 \cdot 4$ & $11 \cdot 4$ & $4 \cdot 0$ & 6.9 & - \\
\hline 18 & - & $19 \cdot 9$ & $12 \cdot 0$ & $2 \cdot 9$ & $14 \cdot 8$ & - \\
\hline 19 & - & $27 \cdot 0$ & $15 \cdot 0$ & $2 \cdot 4$ & $15 \cdot 0$ & - \\
\hline 20 & - & $26 \cdot 3$ & $12 \cdot 0$ & $3 \cdot 0$ & $10 \cdot 0$ & $\operatorname{IgM} 8.3$ \\
\hline 21 & - & $26 \cdot 6$ & $12 \cdot 0$ & $2 \cdot 4$ & $6 \cdot 1$ & $\operatorname{lgG} 3 \cdot 5$ \\
\hline 22 & - & $22 \cdot 0$ & $12 \cdot 6$ & $2 \cdot 8$ & $7 \cdot 4$ & - \\
\hline 23 & - & $22 \cdot 5$ & $9 \cdot 0$ & 1.9 & $2 \cdot 8$ & - \\
\hline
\end{tabular}

TABLE III - Concentrations of tissue plasminogen activator and activities of plasminogen activator inhibitor in the two groups of patients and healthy controls. Values are means (SDs)

\begin{tabular}{|c|c|c|c|c|}
\hline & $\begin{array}{l}\text { Tissue plasminogen } \\
\text { activator }(\mu \mathrm{g} / \mathrm{l})\end{array}$ & p Value & $\begin{array}{c}\text { Plasminogen } \\
\text { activator inhibitor } \\
(\mathrm{U} / \mathrm{ml})\end{array}$ & p Value * \\
\hline \multirow{4}{*}{$\begin{array}{l}\text { Patients with no history } \\
\text { of thrombosis or abortions } \\
\text { (group } 2 ; n=12 \text { ) } \\
\text { Patients with history of thrombosis } \\
\text { or abortions ( } \text { group } 1 ; n=11 \text { ) } \\
\text { Healthy controls }(n=15 \text { ) }\end{array}$} & & \multirow{4}{*}{$\begin{array}{l}<0.002 \\
<0.002\end{array}$} & \multirow{4}{*}{$\begin{array}{c}9 \cdot 0(4 \cdot 3) \\
24 \cdot 8(10 \cdot 7) \\
8 \cdot 0(2 \cdot 8)\end{array}$} & \multirow{4}{*}{$\begin{array}{l}0.0007 \\
0.0002\end{array}$} \\
\hline & $3 \cdot 7(2 \cdot 5)$ & & & \\
\hline & $8 \cdot 4(4 \cdot 0)$ & & & \\
\hline & $4 \cdot 2(1 \cdot 3)$ & & & \\
\hline
\end{tabular}

${ }^{\star}$ Mann-Whitney

plasminogen activator inhibitor activities were found between the patients in group 2 and the controls (tables II and III). Values of tissue plasminogen activator and plasminogen activator inhibitor were significantly correlated $(\mathrm{r}=0 \cdot 80 ; \mathrm{p}=0 \cdot 01)$ in the patients in group 1 . No such correlation was detected in the patients in group $2(r=0 \cdot 32 ; \mathrm{NS})$ or the controls $(r=0 \cdot 29 ; \mathrm{NS})$ (figure). The increase in values of plasminogen activator inhibitor and tissue plasminogen activator was not related to the activity of the disease. Mean values in patients with severely active disease $(n=8$; plasminogen activator inhibitor $18 \cdot 3(\mathrm{SD} 12 \cdot 2) \mathrm{U} / \mathrm{ml}$, tissue plasminogen activator $7 \cdot 6(4 \cdot 4) \mu \mathrm{g} / \mathrm{l})$ were similar to those in patients with moderately active and inactive disease (plasminogen activator inhibitor 15.9 $(10 \cdot 6) \mathrm{U} / \mathrm{ml}$, tissue plasminogen activator $5 \cdot 2(3 \cdot 4)$ $\mu \mathrm{g} / \mathrm{l})$.

Testing for the lupus anticoagulant by measuring the activated partial thromboplastin time gave a positive result in six patients in group 1 and one patient in group 2. When tested by measuring the diluted activated partial thromboplastin time, however, the lupus anticoagulant was detected in all 11 patients in group 1 and one patient in group 2 (table II). To see

TABLE IV-Effect of phosphatidylserine-phosphatidylcholine liposomes on prolonged (five samples) and normal (five samples) diluted activated partial thromboplastin time. Values are means (SDs)

\begin{tabular}{lcc}
\hline & $\begin{array}{c}\text { Prolonged diluted } \\
\text { activated partial } \\
\text { thromboplastin time }\end{array}$ & $\begin{array}{c}\text { Normal diluted activated } \\
\text { partial thromboplastin } \\
\text { time }\end{array}$ \\
\hline $\begin{array}{l}\text { 180 Dilution of Thrombofax reagent } \\
\text { 180 Dilution of Thrombofax reagent + phosphatidylserine- } \\
\text { phosphatidylcholine liposomes }(\mathrm{s})\end{array}$ & $83 \cdot 3(17 \cdot 1)^{\star}$ & $50 \cdot 1(4 \cdot 0)$ \\
$\begin{array}{l}\text { 180 Dilution of Thrombofax reagent + TRIS (s) } \\
\text { t }\end{array}$ & $\begin{array}{l}65 \cdot 5(11 \cdot 8) \\
91 \cdot 5(24 \cdot 5)\end{array}$ & $\begin{array}{l}49 \cdot 8(4 \cdot 5) \\
51 \cdot 0(3 \cdot 3)\end{array}$ \\
\hline
\end{tabular}

${ }^{\star} \mathrm{p}<0 \cdot 02$. whether the prolongation of the diluted activated partial thromboplastin time might have been due to the presence of antiphospholipid antibodies $0.05 \mathrm{M}$ phosphatidylserine-phosphatidylcholine liposomes were added to five samples of plasma mixed with the highest dilution of Thrombofax reagent (180), as described. ${ }^{18}$ Unlike the samples with normal diluted activated partial thromboplastin time, those with liposomes added showed a significant reduction in coagulation time (table IV). This indicated that the prolongation of the diluted activated partial thromboplastin time was due to the presence of antiphospholipid antibodies.

Anticardiolipin antibodies were identified in nine patients in group 1 and four in group 2 . In group 1 there was a greater prevalence of antibodies of the IgG class (table II).

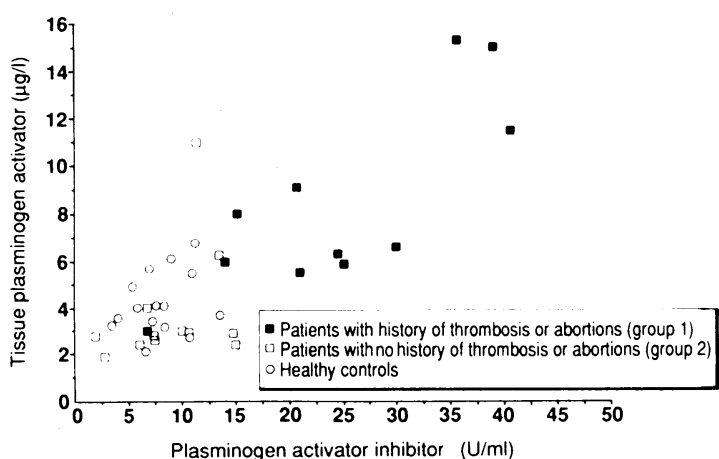

Correlation between tissue plasminogen activator concentrations and plasminogen activator inhibitor activities in patients with and without a history of thrombosis or abortions and in healthy controls

\section{Discussion}

This study shows that in patients with systemic lupus erythematosus complicated by a clinical history of thrombosis or abortions there is a significant increase in tissue plasminogen activator antigen concentrations and plasminogen activator inhibitor activity. Plasminogen activator inhibitor, a protein, inhibits fibrinolysis through the functional blocking of tissue plasminogen activator. ${ }^{22}$ As plasminogen activator inhibitor activity is an expression of the functional interaction between circulating tissue plasminogen activator and plasminogen activator 
inhibitor" our interpretation is that even in the presence of high values of tissue plasminogen activator the increase in its inhibitor is functionally predominant.

The increase in plasminogen activator inhibitor seemed to be characteristic of the patients with a history of thrombosis or abortions, or both, as patients with and without these complications were similar in regard to the activity of their systemic lupus erythematosus. The two groups were also similar in their blood concentrations of $\mathrm{C} 3, \mathrm{C} 4$, fibrinogen, and $C$ reactive protein, indicating that the increase in plasminogen activator inhibitor was not attributable to an exacerbation of their disease.

Paramo et al found high plasminogen activator inhibitor activity in patients who developed postoperative deep vein thrombosis. ${ }^{23}$ In a retrospective study Juhan-Vague et al found high activity in patients who suffered recurrent deep vein thrombosis. ${ }^{12}$ Increased plasminogen activator inhibitor activity may have a role in the thrombotic complications of atherosclerosis, paticularly in the pathogenesis of myocardial infarction. In a prospective study Hamsten et al showed that thrombotic complications were more frequent in young survivors of myocardial infarction who had high plasminogen activator inhibitor activities. ${ }^{24}$

Raised plasminogen activator inhibitor activities in patients with systemic lupus erythematosus and thrombosis may be linked with the presence of the lupus anticoagulant, which is associated fairly frequently with both arterial and venous thrombosis and spontaneous abortion.' We tested for the lupus anticoagulant in all patients by measuring both the activated partial thromboplastin time, which has been a commonly used test for this purpose, 5 and the diluted activated partial thromboplastin time, which has proved to be a more sensitive screening test by virtue of the low phospholipid content. ${ }^{185}$ The rationale for using the diluted activated partial thromboplastin time test is that antiphospholipid antibodies inhibit the coagulation system dose dependently ${ }^{26}$ and may therefore be masked by the higher concentrations of phospholipid in the activated partial thromboplastin time test. The lupus anticoagulant was found in six of our 11 patients with a history of thrombosis or abortions when tested by measuring the activated partial thromboplastin time and in all 11 patients when tested by measuring the diluted activated partial thromboplastin time.

The prolongation of the diluted activated partial thromboplastin time may have been related to anticardiolipin antibodies, which inhibit the coagulation system and were present in 10 of the 12 patients (including the one in group 2) positive for the lupus anticoagulant. This agrees with the data of Harris et al but not with the recent findings of Triplett et al, who identified anticardiolipin antibodies in only $61 \%$ of patients positive for the lupus anticoagulant..$^{2 x}$ This disparity may have been due to the different selection of patients studied and (more probably) the different screening techniques used for detecting the lupus anticoagulant.

We found a significant association between the lupus anticoagulant and high values of plasminogen activator inhibitor in patients with a history of thrombosis or recurrent abortions, or both. This might suggest that the increase in plasminogen activator inhibitor was due to the lupus anticoagulant. Such a relation might be explained by an interaction of the lupus anticoagulant with the endothelium, which might induce a release of tissue plasminogen activator and especially plasminogen activator inhibitor, a reaction that was sug- gested by the significant correlation between tissue plasminogen activator and plasminogen activator inhibitor. Conversely, evidence exists of an interaction between the lupus anticoagulant and the endothelium which results in a reduced activation of protein $\mathrm{C}^{24}$

We conclude that in patients with systemic lupus erythematosus the occurrence of thrombosis and abortions may be linked to an increase in plasminogen activator inhibitor. Although our data suggest that this increase may be due to the presence of the lupus anticoagulant, this needs further study.

We are grateful to Dr Stefania Basili for the statistical analysis and Rae Beno for editorial assistance.

1 Boev ML, Colaco CB, Gharavi AE, Elkon KB, Loizou S, Hughes (iRV. Thrombosis in systemic lupus erythematosus: striking association with the presence of circulating lupus anticoagulant. Br Med f 1983;287:1021-3.

2 Glueck HI, Kant KS, Weiss MA, Pollak VE, Miller MA, Coots $M$. Thrombosis in systemic lupus erythematosus. Arch Intern Med 1985;145: $1389-95$

3 Derksen RHWM, Kater L. Lupus anticoagulant: revival of an old phenomenon. Clin Exp Rheumatol 1985;3:345-57.

+ Hughes GVR. Thrombosis, abortions, cercebral disease, and lupus anticoagulant. Br.Med F 1983;287:1088-90.

5 Lechner $K$. Lupus anticoagulant and thrombosis. In: Verstraete $M$, Vermylen J, Lijnen R, Arnout J, eds. Thrombosis haemostasis. Louvain: Louvain University Press, 1987:525-47.

6 Carreras LO, Machin SJ, Deman R, et al. Arterial thrombosis, intrauterine death and lupus anticoagulant: detection of immunoglobulin interfering with prostacyclin formation. Lancer $1981:-2 \cdot 24-6$

7 Violi F, Valesini G, Iuliano L, Ghiselli A, Falco M, Balsano F. Anticardiolipin antibodies and prostacyclin synthesis. Thromb Haemost 1987:57:374.

8 Hasselaar P, Derksen RHW M, Blokzijl L, de Groot P. Thrombosis associated with antiphospholipid antibodies cannot be explained by effects on endothelial and platelet prostanoid sunthesis. Thromb Haemosi 1988:59:80-5.

9 Harris EN, Gharavi AE, Hughes GRV. Antiphospholipid antibodies. C.linics in Rheumatic Diseases 1985;11:591-609.

10 Angles Cano E, Sultan Y, Clauvel SP. Predisposing factors to thrombosis in systemic lupus erythematosus: possible relation to endothelial cell damage. f L a C Clin . Med 1979:94:313-23.

11 Awada H, Barlowatz-Meimon G, Dougados M, Maisonneuve P, Sultan Y, Amor B. Fibrinolysis abnormalities in systemic lupus erythematosus and their relation to vasculitis. F Lab Clin.14ed 1988;111:229-36.

12 Juhan-Vaguc I, Valadier J, Alessi $M$ C, et al. Deficient t-PA release and elevated PA inhibitor levels in patients with spontaneous or recurrent deep venous thrombosis. Thromb Haemost 1987:57:67-72.

13 Tan EM, Choen AS, Fries JF, at al. The 1982 revised criteria for the classification of systemic lupus erythematosus. Arthritis Rheum 1982;25: $1271-8$

14 Morrow WJW, Isenberg DA, Todd-Pokropek A, Parry HF, Snaith ML. Useful laboratory measurement in the management of systemic lupus ervthematosus of Hed 1982:202:125-38.

15 Cordova C, Violi F, Alessandri C, Ferro D), Saliola M, Balsano F. Prekallikrein and factor V'II as prognostic indices of liver failure. Am $\mathcal{F}$ C/in Pathol 1986;85:579-82.

16 Mancini $G$, Carbonara AO, Heremans JF. Immunochemical quantitation of antigens by single radial immunodiffusion. Immunochemistry 1965;2:235-54

17 Singer JM, Protz CM, Pader E, Elster SK. The latex fixation test. Agglutination test for C-reactive protein and comparison with the capillary precipitin method. Am f Clin Pathol 1957;28:614.

18 Violi F, Ferro D, Valesini G, Quintarelli C, Balsano F. Lupus anticoagulant in liver cirrhosis. Thromb Haemost 1988;2:59.

19 Bergsdorf N, Nilsson T, Wailen P. An enzrme linked immunosorbent assay for determination of tissue plasminogen activator applied to patients with thrombocmbolic disease. Thromb Haemost 1983:50:740-4

20) Chmielewska J, Ranby M. Wiman B. Evidence for a rapid inhibitor to tissue plasminogen activator in plasma. Thromb Res 1983;31:427-36.

21 Valesini G. Harris $N$, Tincani $A$, et al. Use of monoclonal antibodies to identify shared idiotypes on anticardiolipin and anti-DNA antibodies in human sera. Clin Exp Rheumatol 1987:70:18-25.

22 Sprengers K1) Kluft C Plasminogen activator inhibitors, Blood 1987;69. $381-7$.

23 Paramo JA, Alfaro MJ, Rocha E. Postoperative changes in the plasmatic levels of tissue-type plasminogen activator and its fast-acting inhibitor. Relationship to deep vein thrombosis and influence of prophylaxis. Thromb Haemos 1985:54:713-6.

24 Hamsten $\mathrm{A}, \mathrm{De}$ Faire $\mathrm{U}$, Walldius (i, ct al. Plasminogen activator inhibitor in plasma: risk factor for recurrent myocardial infarction. Lancet 1987;ii:3-9.

25 Alving BM, Baldwin PE, Richards RI, Jackson BS. The dilute phospholipid al'T': a sensitive method for verification of lupus anticoagulants. Thromb Haemosi 1985:54:709-12.

26 Violi F, Valesini (G, Ferro D), Tincani A, Balestrieri G, Balsano F. Anticeagulant activity of anticardiolipin antibodies. Thromb Res 1986;44:543-8.

27 Harris EN, Gharavi AE, Boey ML, et al. Anticardiolipin antibodies: detection by radioimmunoassay and association with thrombosis in systemic lupus erythematosus, Lancet 1983;ii:1211-4.

28 Triplett DA, Brandt JT, Musgrave KA, Orr CA. The relationship between lupus anticoagulant and antibodies to phospholipid. FAMA 1989;259

29 Cariou R, Tobelem G, Soria C, Caen J. Inhibition of protein C activation by endothelial cells in the presence of lupus anticoagulant. N lingl .7. Med 1986;314:1193-4

Accepted 2 Fibruary 1990 